\title{
Name Changes in Israel
}

\section{GURTIS ADLER}

N ISRAEL'S RETURN AS A SOVEREIGN STATE after an interval of some two thousand years, the Hebrew language became the government's official mouthpiece, the language of its Biblical ancestry. It is quite natural therefore that many of Israel's inhabitants, in keeping with their mission, desired to erase all connections with the past and leave its painful traces behind them. To accomplish this they assumed Hebrew names in lieu of those they formerly had.

Sahavy (golden). Goldin from Russia proudly displays his new name Sahavy meaning "golden." Goldschmidt, who came from Germany, chose the same name, but spelled it with ' $Z$,' Zahavy. He omitted -schmidt from the name entirely, but retained the gold.

Some persons named Zlotnik, born in Poland, took a different view. Though their name personifies goldsmith, they chose the name Avida, which embraces the general term "work," emphasizing any kind of craftsmanship.

Aven (stone). Steiner, which is a German name, sounds somewhat hard. And so, it yielded perfect repose and euphony in the Israeli name Avni (stony). In this adjective sense the name sounds melodious. This result is brought about by the mere change of form from noun to adjective. Similarly, stony, in the place name Stony Brook is more palatable than stone brook.

Lowenstein apparently finds solace in the translated version Avnari, behind which lies the explanation "lion chiseled in stone."

Gefen (vine). What might be called an adaptation, Polish born Weinstein (vine jug or stone) called himself Gefen (vine). Another, Weinreich adopted for his new name Carmon from caram, signifying the source from which vine is derived, "vineyard."

Ben-(son of). Egyptian born Bloom, bearing an anglicized 
name, discarded it for the sparkling natural phenomena Benor, prototype for "the son of light." And Schpectoroff of RussianJewish background, to escape the idea of former haunted scenes, went forth as Benshemesh, meaning "son of the sun." Birnzweig, German for "pear twig," became Benyamini (son of my right hand). Bessarabian born Braverman, changed his name to BenSimha, which echoes the virtues of delight. Ben-Baruch, "portrait of the son of blessedness," preferred his new name to that of Schwartz, which is German for "black."

$\operatorname{Bar}$ (Son). Bar is the Aramaic form for the Hebrew 'Ben.' In that form, Canadian born Lyons took refuge at the house of David by perpetuating his name as Bar-David, "son of David." And Michael Lubarsky was brief and concise. He became known as plain Michael Bar.

$A v$-(father). The counterpart of the prefix Ben (son) is the prefix Av (father). Accordingly, the popular name Grossman gave way to the Biblical symbol Avinoam (father of pleasantness). Formerly known as Reuben Grossman, the Hebrew poet, he now is identified as Reuben Avinoam.

Elimelech Selikowitz has been transformed to Elimelech Avner (father of light), the first name Elimelech signifying "my God and King."

The double name of Polish born Mahler-Kalkstein is simplified in the new designation Avidom (earthly father), and former von Friedman acquired the name Avissar, "princely father."

Aizenberg, originally spelled Eisenberg (German, iron mount) has projected itself into the iron-ribbed Israeli name Barsilay, meaning the same.

Kaluzinski, of Polish extraction, started a new life under the Hebrew name Arieli, expressive of the lion God, while, Boretzki, captured the wonders of Barak in the phenomena of 'lightning.'

Amir (to command) has been exchanged for 'Weissman.' And Gruenfeld from Berlin in praise for deliverance adopted the name symbol Gadiesh (overflowing).

Emulation of Biblical heroes is another favored practice. Evserov, a native of Siberia perpetuated this attitude by calling himself Ezer (help). Ezra, the Biblical hero and priest of the Book of Ezra, who five hundred years before Christ led the Jews back from captivity, must have influenced this choice. 